\title{
The Functional Relevance of Prepro-melanin Concentrating Hormone (pMCH) to Skin Color Change, Blind-side Malpigmentation and Feeding of Oliver Flounder Paralichthys olivaceus
}

\author{
Duk-Young Kang*, Hyo-Chan Kim and Han-Seung Kang \\ West Sea Fisheries Research Institute, National Fisheries Research and Development Institute, Incheon 400-420, Korea
}

\begin{abstract}
To assess the functional structure of prepro-melanin-concentrating hormone (pMCH), we isolated and cloned $\mathrm{pMCH}(o f-\mathrm{pMCH})$ mRNA from the brain of the olive flounder, Paralichthys olivaceus, and compared its amino acid sequence with those from other animals. In addition, to examine whether activation of the brain of-pMCH gene is influenced by background color, density, and feeding, we compared pMCH mRNA activities against different background colors (bright and dark) and at different densities (100\% PCA and 200\% PCA). To examine whether the pMCH gene is related with malpigmentation of blind-side skin and appetite, we compared pMCH gene expression between ordinary and hypermelanic flounders, and between feeding and fasting flounders. The of-pMCH cDNA was $405 \mathrm{bp}$ in the open reading frame [ORF] and encoded a protein of 135 amino acids; MCH was $51 \mathrm{bp}$ in length and encoded a protein of 17 amino acids. An obvious single band of the expected size was obtained from the brain and pituitary by RT-PCR. In addition, of-pMCH gene activity was significantly higher in the bright background only at low density $(<100 \%$ PCA) making the ocular skin of fish whitening, and in ordinary fish. However, the gene activity was significantly decreased in dark background, at high density ( $>200 \%$ PCA), and in hypermelano fish. These results suggest that skin whitening camouflage of the flounder is induced by high $\mathrm{MCH}$ gene activity, and the density disturbs the function of background color in the physiological color change. Moreover, our data suggest that a low level of MCH gene activity may be related to malpigmentation of the blind-side skin. In feeding, although pMCH gene activity was significantly increased by feeding in the white background, the $\mathrm{pMCH}$ gene activity in the dark background was not influenced by feeding, indicating that the MCH gene activity increased by feeding can be offset by dark background color, or is unaffected by appetite. In conclusion, this study showed that MCH gene expression is related to ocular-skin whitening camouflage and blind-skin hypermelanosis, and is influenced by background color and density.
\end{abstract}

Key words: Blind-skin malpigmentation, Camouflage, Color change, Feeding, MCH, Paralichthys olivaceus

\section{Introduction}

The primary structure of melanin-concentrating hormone $(\mathrm{MCH})$, which is produced in neurons in the hypothalamus and released from the neurohypophysis, was first identified in chum salmon, Oncorhynchus keta (Kawauchi et al., 1983), and has been investigated mostly in spindle-shaped teleosts: Chinook salmon, Oncorhynchus tshawytscha (Minth et al., 1989); coho salmon, Oncorhynchus kisutch (Nahon et al., 1991); rainbow trout, Oncorhynchus mykiss (Berman et al., 2009);
(C) 2014 The Korean Society of Fisheries and Aquatic Science This is an Open Access article distributed under the terms of the Creative Commons Attribution Non-Commercial Licens (http://creativecommons. org/licenses/by-nc/3.0/) which permits unrestricted non-commercial use, distribution, and reproduction in any medium, provided the original work is properly cited.
Received 4 August 2014; $\quad$ Revised 12 September 2014

Accepted 15 September 2014

*Corresponding Author

E-mail: dykang69@gmail.com 
tilapia, Oreochromis mossambicus (Groneveld et al., 1995); and bonito, Katsuwonus pelamis (Kawauchi, 1989). MCH acts as a functional antagonist of $\alpha-\mathrm{MSH}$ and aggregates pigment-containing melanosomes around the nucleus in pigment cells (Kawauchi et al., 1983), thereby lightening the color of fish scales and skin (Kawauchi and Baker, 2004). Therefore, $\mathrm{MCH}$ is also generally accepted as a key regulator of physiological color changes in fish (Kishida et al., 1989; Suzuki et al., 1995; Kawauchi and Baker, 2004; Kawauchi, 2006). The physiological color changes refer to the direct effects of environmental factors, such as light, background color, and social context, on pigment migration (Nery and Castrucci, 1997; Oshima, 2001). The physiological color change is caused by centripetal and centrifugal movements of pigments in satellite chromatophores, which are determined by many environmental factors, including background pattern (Ramachandran et al., 1996), density stress (Doolan et al., 2008), luminosity (Han et al., 2005), and nutrition (Kalinowski et al., 2005).

Other studies have indicated that $\mathrm{MCH}$ and $\alpha-\mathrm{MSH}$ (antagonist of $\mathrm{MCH}$ ) are commonly involved in morphological color change, as well as in the rapid color change of fish that results in skin darkening (Höglund et al., 2002; Sugimoto, 2002). Indeed, it was shown that intraperitoneal injection of $\mathrm{MCH}$ turned the ocular skin pale in barfin flounder (Verasper moseri), and a high level of $\mathrm{MCH}$ suppressed blind-side hypermelanosis (Takahashi et al., 2004; Amiya et al., 2005; Yamanome et al., 2005; Takahashi et al., 2007; Kobayashi et al., 2008), suggesting that MCH may participate in the morphological color change in fish. Blind-side hypermelanosis is common in cultured flatfishes and is economically important (Jeong and Jeon, 2008). When flatfishes reared at high density (Seikai, 1992; Takahashi, 1994; Tagawa et al., 2004; Kang et al., 2011), this malpigmentation develops in tanks that lack sandy substrata (Ottesen and Strand, 1996; Iwata and Kikuchi, 1998; Kang and Kim, 2012) and is induced by a dark background color (Yamanome et al., 2007b). However, questions remain regarding whether the $\mathrm{MCH}$ in flatfishes is functionally related to the abnormal morphological color change, and little information is available regarding the involvement of $\mathrm{MCH}$ in the morphological color changes. Therefore, it is necessary to search for evidence of this in other species.

In mammals, the neurons in which $\mathrm{MCH}$, as a hypothalamo-pituitary peptide hormone, is produced are the most downstream peptidergic neurons involved in the chain of hypothalamic signals that regulate food intake and energy homeostasis (Pritchard et al., 2002; Shi, 2004; Pissios et al., 2006). A series of studies using rodents established the roles of $\mathrm{MCH}$ signaling in the regulation of food intake and energy balance in mammals (Presse et al., 1996; Qu et al., 1996; Rossi et al., 1997; Ludwig et al., 1998; Stricker-Krongrad et al., 2001; Della-Zuana et al., 2002; Abbott et al., 2003; Gomori et al., 2003). However, despite the known involvement of $\mathrm{MCH}$ in feeding and somatic growth in mammals, little information is available regarding its effects on food intake in fish. Thus, the effects of $\mathrm{MCH}$ on feeding behavior in fish remain to be explored. Some studies (Lin et al., 2000; Matsuda et al., 2006; Matsuda et al., 2007; Pérez Sirkin et al., 2012) have suggested that $\mathrm{MCH}$ is involved in the regulation of food intake and energy balance in teleosts. Experiments in barfin flounder suggested that teleost $\mathrm{MCH}$ is associated with food intake (Takahashi et al., 2004). However, recent studies indicating that fish possess two forms of $\mathrm{MCH}$ precursors (Berman et al., 2009; Tuziak and Volkoff, 2012) suggest that the two prohormones likely have different roles in physiological color change and feeding behavior; fish-type $\mathrm{MCH}(\mathrm{MCH} 1)$ expression may be correlated with pigmentation changes, but increased mammalian-type $\mathrm{MCH}(\mathrm{MCH} 2)$ expression may occur in response to chronic food deprivation. However, there is currently insufficient data to determine the functional role of the fish-type $\mathrm{MCH}$ gene in feeding. Therefore, it is necessary to clarify the functional relationships between the fish-type $\mathrm{MCH}$ genes with respect to appetite.

In the present study, we first determined the primary structure of the fish-type prepro-MCH of olive flounder ( of-pMCH) by cloning and peptide analysis of brain tissue, identified the sequence of $o f-\mathrm{pMCH}$, and examined the structural features of $o f$-pMCH. Then, to examine whether the of-pMCH gene is related to physiological color change against background color, and whether density influences the physiological color change and gene activation, we compared pMCH mRNA activities against two background colors (white and dark-green) at two densities (100\% PCA and 200\% PCA). To determine whether the fish-type $\mathrm{MCH}$ gene is related to blind-side malpigmentation and appetite, we compared of-pMCH gene expression between ordinary and hypermelanic flounders and between feeding and fasting flounders.

\section{Materials and methods}

\section{Identification of the of-pMCH gene}

To isolate of-pMCH, we sampled the whole brain of one ordinary flounder (TL $16.2 \pm 0.2 \mathrm{~cm}, \mathrm{BW} 41.9 \pm 1.9 \mathrm{~g}$ ). Total RNA was extracted from the sampled brain using the PureLink Micro-to-Midi Total RNA Purification System (Invitrogen, Carlsbad, CA). Genomic DNA in extracted tissue was eliminated using recombinant DNase I solution (Promega, Madison, WI) in accordance with the manufacturer's protocol. Then, we measured total RNA content in the extracted tissue with a Nanovue Plus Spectrophotometer (GE Healthcare, Buckinghamshire, UK). The concentration of total RNA was determined by measuring the absorbance at $260 \mathrm{~nm}\left(\mathrm{~A}_{260}\right)$. The quality and integrity of the total RNA were assessed based on the ratio of $\mathrm{A}_{260}$ to $\mathrm{A}_{280}$ and by visualization of $28 \mathrm{~S}$ and $18 \mathrm{~S}$ rRNA bands on $1 \%$ agarose gels. The average of the $\mathrm{A}_{260} / \mathrm{A}_{280}$ ratio was $2.12 \pm 0.01(n=20)$.

Reverse transcription and PCR (RT-PCR) amplification 
were performed to detect partial strand of pMCH mRNA. RTPCR primers (Table 1) were designed from highly conserved regions of pMCH from barfin flounder (GenBank BAC82350). PCR amplification were performed using AccuPower RT/PCR PreMix (Bioneer, Daejeon, Korea) with MyiQ PCR system (Bio-Rad, Hercules, CA) according to the manufacturer's instructions. The amplified PCR product was separated on an agarose gel, extracted using the AccuPrep Gel Purification Kit (Bioneer), and sequenced by COSMO Gen Tech. (Seoul, Korea). A single PCR product of the expected size (280 bp) was obtained.

For rapid amplification of the cDNA-ends (RACE) reactions, gene-specific primers (GSP) were selected from the 280 bp PCR product obtained by RT-PCR (Table 1). For RACE, the RACE primers supplied with the CapFishing Full-Length cDNA Premix Kit (Seegene, Seoul, Korea) was used as the sense and anti-sense primers. After preincubation at $94^{\circ} \mathrm{C}$ for $180 \mathrm{~min}, \mathrm{PCR}$ was carried out for 35 cycles of denaturation at $94^{\circ} \mathrm{C}$ for $40 \mathrm{~s}$, annealing at $55^{\circ} \mathrm{C}$ for $40 \mathrm{~s}$, and extension at $72^{\circ} \mathrm{C}$ for $60 \mathrm{~s}$, followed by an extension step of $5 \mathrm{~min}$ at $72^{\circ} \mathrm{C}$. After RACE, we obtained target cDNA $5^{\prime}$ - and $3^{\prime}$-RACE products that shared an overlapping region. The full-length cDNA was generated by direct PCR using 5'- and 3'-RACE fragments.

The full-length cDNA was inserted into a PCR cloning vector using a TOPO TA Cloning Kit (Invitrogen), which was then transformed into Escherichia coli cells. The cells were spread on lysogeny broth (LB) plates and incubated overnight at $37^{\circ} \mathrm{C}$. The white or light-blue colonies were picked and cultured overnight in LB medium. Plasmid DNA was purified using a QIAprep Spin Miniprep Kit (Qiagen, Crawley, UK), and then digested with $E c o$ RI at $37^{\circ} \mathrm{C}$ for $1 \mathrm{~h}$. Finally, the plasmid
DNA was sequenced by Macrogen (Seoul, Korea). The amino acid sequence of of-pMCH was compared to those deduced from cDNAs of other teleost species and mammals.

\section{pMCH tissue distribution analysis and phyloge- netic tree}

The brain (B), pituitary (P), liver (L), eye (E), kidney (K), gill $(\mathrm{G})$, heart $(\mathrm{H})$, stomach $(\mathrm{S})$, intestine $(\mathrm{I})$, muscle $(\mathrm{M})$, testis (Te), ocular skin (Os), and blind skin (Bs) were removed from ordinary olive flounder (TL $16.2 \pm 0.2 \mathrm{~cm}, \mathrm{BW} 41.9 \pm 1.9 \mathrm{~g}$; $n=5$ ) and stored at $-70^{\circ} \mathrm{C}$ until required for investigation of the tissue distribution of pMCH by RT-PCR. First, pMCHspecific RT-PCR primers for tissue distribution analyses were designed as Table 2. Then, Reverse transcription and PCR (RT-PCR) amplification were performed using the sampled tissues. We investigated whether a single band of the expected size (390 bp) was amplified from all sampled tissues. In addition, Multiple-sequence alignment of nucleotides and amino acids were performed using ClustalW at MEGA 4.1 BETA and GeneDoc (version 2.7). Sequences for other animals pMCH genes were retrieved from the NCBI site (www.ncbi.nih.gov) using the GenBank database. Then, we compared the amino acid sequences of of-pMCH with the pMCH sequences of other fishes and manmals sequences. Also, we constructed a phylogenetic tree of ray-finned fish and vertebrate $\mathrm{pMCH}$ genes via the neighbor-joining method (NJ method; p-distance $=0.05$ ) using the MEGA4.1 program (Tamura et al., 2007) based on amino acid differences (p-distance) and complete deletion. The reliability of the tree was assessed by bootstrapping (1,000 replications), and the tree is rooted from human pMCH (pMCH/GenBank AAH18048).

Table 1. Primers used for the isolation of MCH 1 \& 2 cDNAs, the synthesis of full length- first strand CDNA and the $5^{\prime}$-and $3^{\prime}$-RACEs

\begin{tabular}{|c|c|c|c|c|}
\hline Gene & Clone & Primer position & Primers & Size \\
\hline \multirow[t]{4}{*}{$\mathrm{MCH}$} & I(RT-PCR) & $\begin{array}{l}\text { sense }(152 \sim 171) \\
\text { antisense }(412 \sim 431)\end{array}$ & $\begin{array}{l}\text { 5'-TACCCATGGCCAAGACTGAA-3' } \\
\text { 5'-CTCCTCAGGATGGGGATGTT-3' }\end{array}$ & $280 \mathrm{bp}$ \\
\hline & $\mathrm{II}\left(5^{\prime}-\mathrm{RACE}\right)$ & $\begin{array}{l}\text { sense }(-22 \sim-1 ; \text { kit }) \\
\text { antisense }(283 \sim 302, \text { GSP })\end{array}$ & $\begin{array}{l}\text { 5'-GTCTACCAGGCATTCGCTTCAT-3' } \\
\text { 5'-GGATCGGCGACAACGATTAT-3' }\end{array}$ & $325 \mathrm{bp}$ \\
\hline & III(3'-RACE) & $\begin{array}{l}\text { sense (223 } \sim 242, \text { GSP) } \\
\text { antisense }(623 \sim 644 \text {; kit) }\end{array}$ & 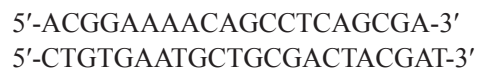 & $422 \mathrm{bp}$ \\
\hline & IV(end-to-end) & $\begin{array}{l}\text { sense }(-22 \sim 302) \\
\text { antisense }(223 \sim 644)\end{array}$ & $\begin{array}{l}5^{\prime} \text {-end target cDNA } \\
3^{\prime} \text {-end target cDNA }\end{array}$ & $623 \mathrm{bp}$ \\
\hline
\end{tabular}

Table 2. Gene specific primers used to analyze tissues distribution and compare mRNA expression between groups

\begin{tabular}{|c|c|c|c|c|c|c|}
\hline Gene & Primer position & Primers & Product size & $\operatorname{MT}\left({ }^{\circ} \mathrm{C}\right)$ & $\mathbf{R}^{2}$ & E (\%) \\
\hline $\begin{array}{l}\text { MCH } \\
\quad(\text { GenBank EU232720) }\end{array}$ & $\begin{array}{l}\text { Sense }(5-25) \\
\text { Antisense }(106-125)\end{array}$ & $\begin{array}{l}\text { 5'-GGCAGTCGTTCATGTCCATC-3' } \\
\text { 5'-GAGCAGGAAACTTGGCCTC-3' }\end{array}$ & $121 \mathrm{bp}$ & 85.0 & 0.998 & 100 \\
\hline $\begin{array}{l}\text { 18S rRNA } \\
\text { (GenBank EF126037) }\end{array}$ & $\begin{array}{l}\text { Sense }(1219 \sim 1229, \mathrm{GSP}) \\
\text { Antisense }(1320 \sim 1339, \mathrm{GSP})\end{array}$ & $\begin{array}{l}\text { 5'-GACTCAACACGGGAAACCTCA-3' } \\
\text { 5'-CAGACAAATCGCTCCACCAA-3' }\end{array}$ & $121 \mathrm{bp}$ & 84.0 & 0.994 & 92.9 \\
\hline
\end{tabular}

$M T$, melting temperature; $R^{2}$, Pearson correlation coefficient; $E$, real-time PCR efficiency $\left(E=10^{[-1 / 1 / \text { lope }]}\right)$. 

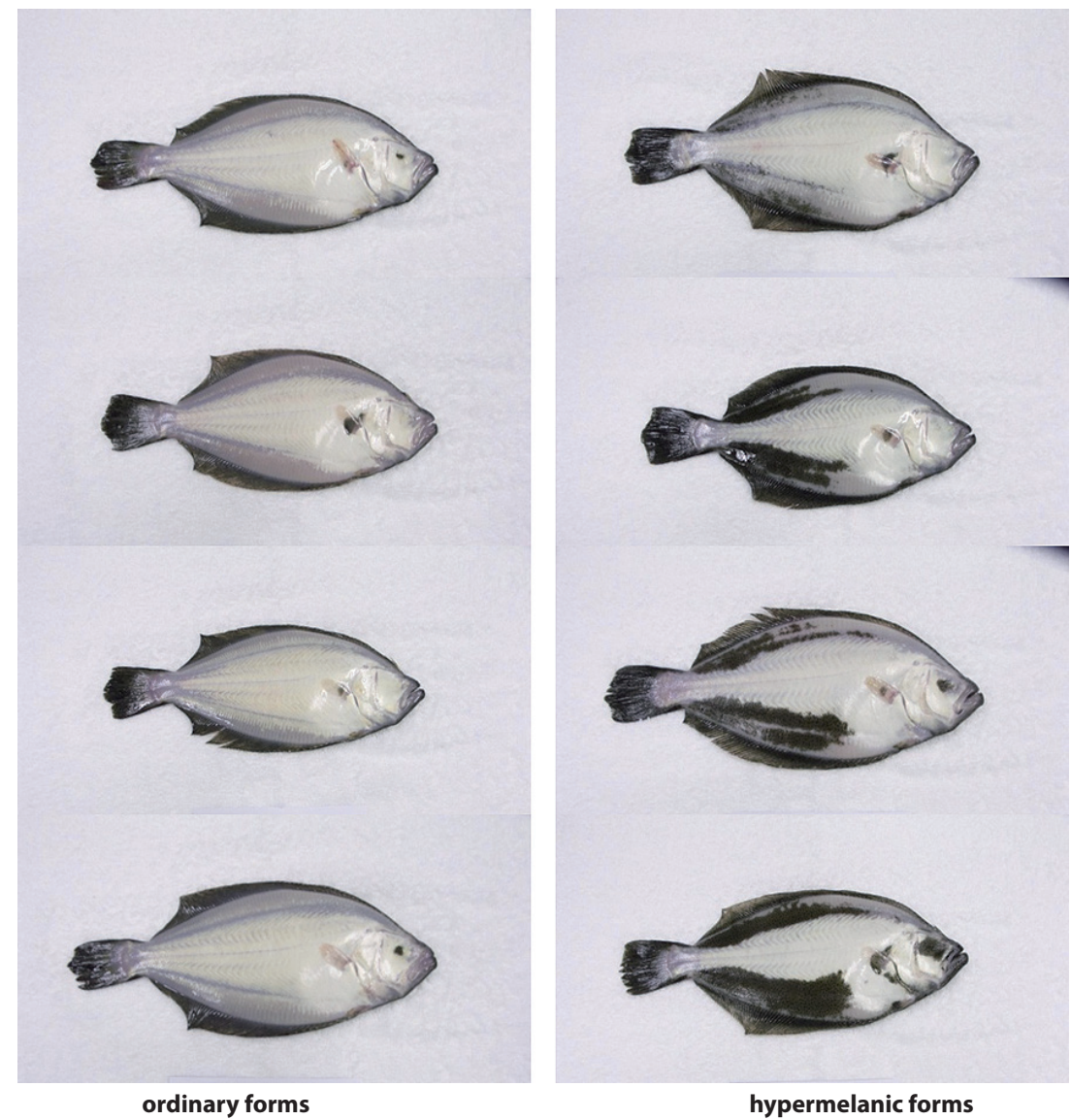

Fig. 1. Photographs of ordinary and hypermelanic olive flounders Paralichthys olivaceus.

\section{Influence of background color, density, and ap- petite on $\mathrm{MCH}$ gene expression}

\section{Experimental animals and experimental conditions}

To evaluate the influence of density and background color on of-pMCH gene expression, size-matched ordinary flounders (TL $20.8 \pm 0.5 \mathrm{~cm}, \mathrm{BW} 91.7 \pm 6.5 \mathrm{~g}$ ) were randomly divided into two groups and transferred to dark-green and white tanks $\left(1000 \mathrm{~L} / \mathrm{m}^{3}\right)$, where they were reared at a density of $30 \mathrm{fish} / \mathrm{m}^{2}(\mathrm{PCA}=100 \%)$ or $60 \mathrm{fish} / \mathrm{m}^{2}(\mathrm{PCA}=200 \%)$ for 10 days. Five fish were then sampled from each group reared on white and dark-green backgrounds, and the brains were extracted. In addition, to assess the relevance of $\mathrm{MCH}$ to blind-side hypermelanosis, we size-matched ordinary and hypermelanic flounders (TL $21.4 \pm 0.1 \mathrm{~cm}, \mathrm{BW} 87.9 \pm 5.2 \mathrm{~g}$ ) that were reared in flat-bottomed and gravel-bottomed darkgreen FRP tanks $\left(1000 \mathrm{~L} / \mathrm{m}^{3}\right)$ for 120 days, respectively, and then sampled the brains from five fish of the ordinary and hypermelanic groups (Fig. 1).

To determine whether $\mathrm{MCH}$ gene expression is related to food intake, we randomly divided size-matched hypermelanic flounders (TL $33.2 \pm 1.31 \mathrm{~cm}, \mathrm{BW} 468.5 \pm 72.82 \mathrm{~g}$ ) into feeding and fasting groups, and transferred the fish from the two groups into dark-green and white tanks $\left(1000 \mathrm{~L} / \mathrm{m}^{3}\right)$ at a density of $10 \mathrm{fish} / \mathrm{m}^{2}(\mathrm{PCA}=50 \%)$. The fish were acclimated to each tank supplemented with food for 3 days. After 3 days, we continuously supplied food to fish in one group (feeding group), while those in the other group were deprived of food (fasting group) for 7 days. On the final day, we sampled five fish from the dark-green and white tanks in the feeding and fasting groups and extracted the brains. Sampled fish were euthanized with the general anesthetic 2-phenoxyethanol (1/1000 dilution, $0.3-0.4 \mathrm{mg} / \mathrm{L}$ ), and then rinsed with distilled water to remove salt. The brain tissues were removed from flounders and stored at $-70^{\circ} \mathrm{C}$ for comparison of $\mathrm{pMCH}$ mRNA expression.

\section{Comparison of of-pMCH mRNA expression}

To measure pMCH mRNA expression levels in the brain, we extracted total RNA from the whole brains of flounders $(n=15)$ using a Maxwell 16 LEV simplyRNA tissue kit (Promega) and Promega Maxwell 16 instrument, and then elimi- 


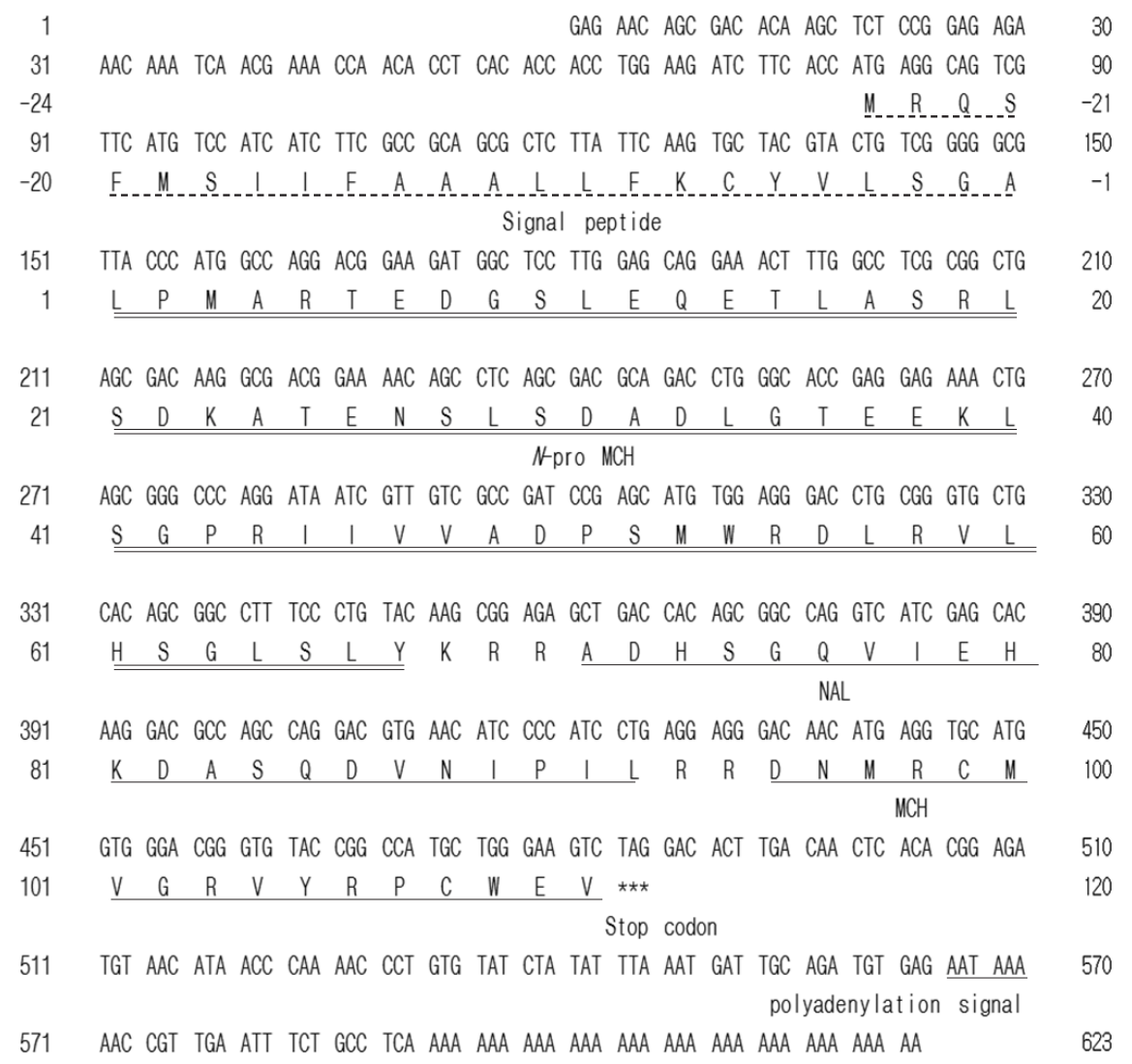

Fig. 2. Structure of of-pMCH cDNA. The nucleotide sequence of of-pMCH cDNA (not including the poly-A tail) and deduced amino acid sequence. Positions of nucleotides and amino acid residues are indicated on both sides. The N-terminus of pro-MCH in the deduced amino acid sequence of pMCH is designated position 1. The signal peptide is indicated by a broken line. N-pro MCH, NAL, and MCH are distinguished by underlining. The underline in the 3 '-untranslated region shows the polyadenylation signal. (**) Stop codon.

nated genomic DNA from the extracted tissue using DNase I (Promega). In addition, samples were subjected to treatment with DNAse I to remove contaminating genomic DNA in the total RNA samples.

Aliquots of $1 \mu \mathrm{g}$ of total RNA were reverse-transcribed to cDNA using an iScript cDNA Synthesis Kit (Bio-Rad). We then performed real-time PCR using the IQ SYBR Green Supermix (Bio-Rad).

To compare mRNA expression between groups, the qPCR gene-specific primers (GSP) of of-pMCH used in the tissue distribution analyses were used again, and primers for $18 \mathrm{~S}$ ribosomal RNA (rRNA) (GenBank EF126037) were newly designed to serve as a housekeeping gene control (Table 2). The housekeeping gene was unaffected by feeding regimen and background color in the brain as determined by examination of Ct values. The real-time PCR amplification efficiencies and R2 for each primer pair were calculated from the given slopes using the CFX-96 Manager software. The corresponding realtime PCR efficiency (E) of one cycle in the exponential phase was calculated according to the equation: $E=10^{[-1 / \text { slope }]}$. The transcripts investigated showed high real-time PCR efficiency rates and linearity (Table 2).

These data were used to produce real-time amplification curves for $\mathrm{pMCH}$ by plotting the $\Delta$ normalized reporter against the cycle number. The cycle threshold $(\mathrm{Ct})$ value, which is the PCR cycle at which a statistically significant increase in reported fluorescence above the baseline could be detected (set at $\Delta \mathrm{Rn}=0.2$ ), was determined for $\mathrm{pMCH}$. The $\mathrm{Ct}$ values were used in the comparative $\mathrm{Ct}$ method (Livak and Schmittgen, 2001) in accordance with the manufacturer's protocol (Bio-Rad) for relative quantification. We evaluated the expression of $18 \mathrm{~S}$ rRNA mRNA in each reaction as a control. The expression levels in the two tissues were normalized with respect to the $18 \mathrm{~S}$ rRNA signal and expressed as the relative expression level.

\section{Statistical analysis}

The data were analyzed by Mann-Whitney U-test using SPSS (Korean ver. 7.50; SPSS Inc., Chicago, IL). In all analyses, $P<0.05$ was taken to indicate statistical significance. 

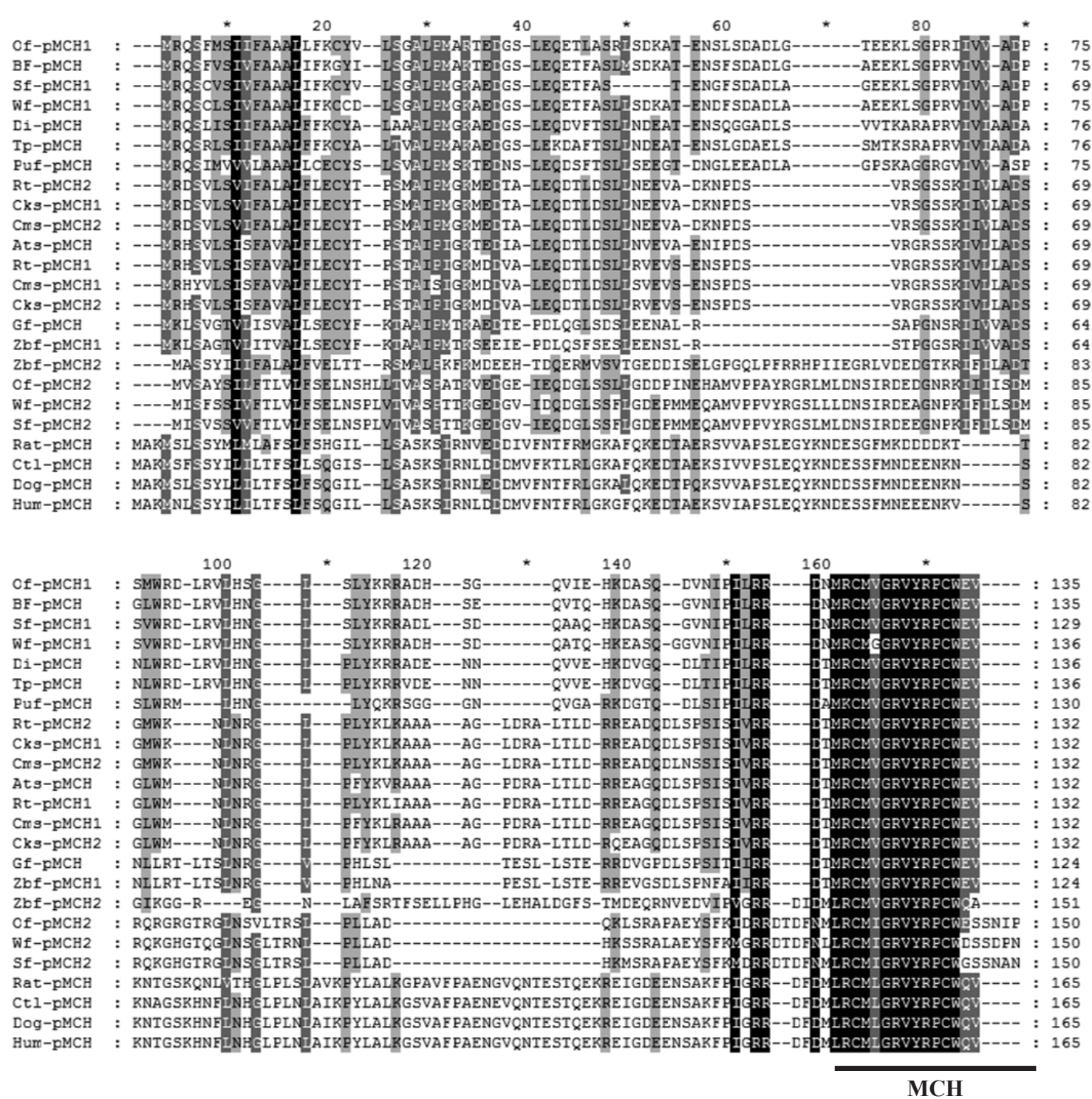

Fig. 3. Comparison of the of-pMCH amino acid sequence (of-pMCH1, GenBank ABY73341; of-pMCH2, GenBank AAF67166) with those of barfin flounder (bf-pMCH, GenBank BAC82350.1), starry flounder (sf-pMCH1, GenBank KF621304; sf-pMCH2, GenBank KF621305), winter flounder (wf-pMCH1, GenBank AEE36642; wf-pMCH2, GenBank AEE36640), dimerus (di-pMCH, GenBank ACT33940), Mozambique tilapia (tp-pMCH, GenBank CAA57050), green spotted puffer, (puf-pMCH, GenBank CAF93560), rainbow trout ( $r t-p M C H 1$, GenBank CAA52059; rt-pMCH2, GenBank CAA52060), Chinook salmon (cks-pMCH1, GenBank AAA49422; cks-pMCH2, GenBank AAA49423), chum salmon (cms-pMCH1, GenBank AAA49418; cms-pMCH2, GenBank AAA49419), Atlantic salmon (ats-pMCH, GenBank ACl70019), goldfish, Carassius auratus ( $g f-\mathrm{pMCH}$, GenBank CAL48577), zebrafish (zbf-pMCH1, GenBank ACO35933; zbf-pMCH2, GenBank ACO35934), cattle (ctl-pMCH, GenBank ABF59972), dog (dog-pMCH, GenBank AAU43637), rat (rat-pMCH, GenBank AAA41580), and human (humpMCH, GenBank AAH18048).

\section{Results}

\section{Identification of of-pMCH cDNA}

A PCR-based cloning strategy (RT-PCR followed by 3'and $5^{\prime}$-RACE) was used to clone a cDNA encoding a putative pMCH from the olive flounder brain (Table 1). The first PCR using stage-I sense and antisense primers amplified the middle region (nt 152-431; clone I). Based on this nucleotide sequence, a stage-II antisense primer was synthesized for 5'-RACE. PCR using the stage-II antisense primer and a 5'RACE kit primer (abridged universal amplification primer) amplified the of-pMCH cDNA (nt 1-302; clone II). Based on clones I and II, a stage-III sense primer was synthesized for 3'RACE. Clone III encoding of-pMCH cDNA (nt 223-590) was amplified using the stage-III sense primer $\mathrm{C}$ and 3'-RACE kit 


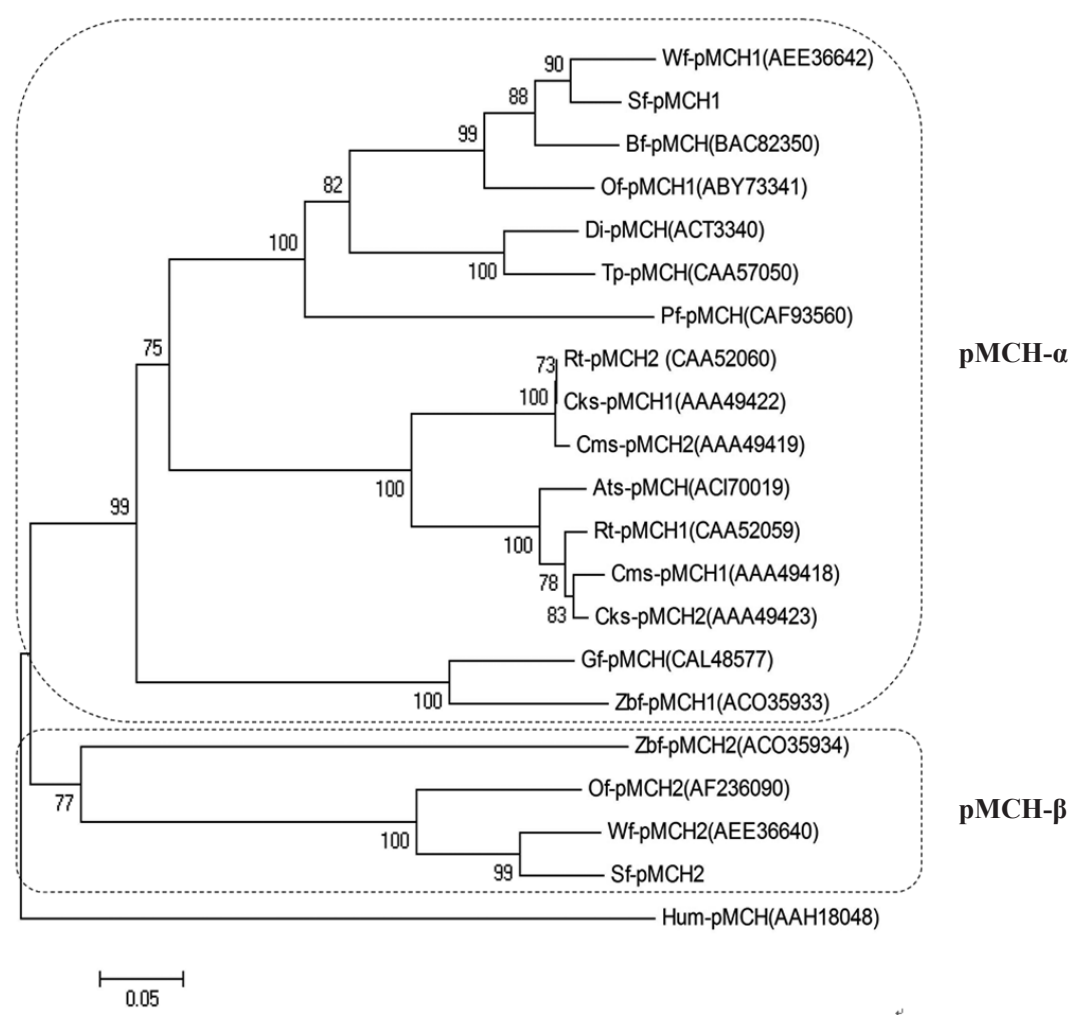

Fig. 4. Consensus phylogenetic tree constructed with the fish $\mathrm{pMCH}$ amino acid sequences by neighbor-joining analysis based on amino acid differences (p-distance). The tree is rooted from human pMCH (GenBank AAH18048). Reliability of the tree was assessed by bootstrapping $(1,000$ replications).

primer (clone III). The three PCR-amplified cDNAs were then merged to provide the entire sequence of of-pMCH cDNA. Based on our data, the of-pMCH cDNA (GenBank accession no. ABY73341) has a 405 bp ORF, which starts with an ATG codon at nt 79 and ends with a TAA stop codon at nt 483 (Fig. 2). The of-pMCH cDNA encodes 135 amino acids and consists of a signal peptide, N-terminal peptide (N-pro $\mathrm{MCH}$ ), neuropeptide AL (NAL), and $\mathrm{MCH}$. The amino acid sequence (aa) -24 to -1 of $\mathrm{pMCH}$ is referred to as the signal peptide, and aa $1-67$ of pMCH is referred to as N-pro MCH. The NAL is located at aa 71-92, and $\mathrm{MCH}$ is located at the C-terminal end (aa 95-111) of of-pMCH. The of-MCH cDNA amino acid sequence encoded a deduced product of 17 amino acid residues (DNMRCMVGRVYRPCWEV) (Fig. 2).

\section{Comparison of of-pMCH with vertebrate pMCHs, and phylogenetic analysis}

The amino acid sequence of $o f-p M C H$ was compared with those deduced from the $\mathrm{pMCH}$ cDNAs of other vertebrate species (Fig. 3). The levels of amino acid sequence identity of ofpMCH were $85 \%$ with pMCH of barfin flounder, $80 \%$ with $s f$ $\mathrm{pMCH} 1$ and $w f-\mathrm{pMCH} 1,68 \%$ with $d i-\mathrm{pMCH}$ and $t p-\mathrm{pMCH}$, $42-43 \%$ with salmonid species pMCHs, $32 \%$ with $g f-\mathrm{pMCH}$,
$29 \%$ with $z b f$-pMCH1, 25\% with $z b f$-pMCH2, 26\% with ofpMCH2, 24\% with $s f-\mathrm{pMCH} 2$ and $w f-\mathrm{pMCH} 2$, and 19-20\% with mammalian pMCHs, and 19\% with Hum-pMCH.

The relationships among a number of pMCHs are shown in a phylogenetic tree constructed by the NJ method (Fig. 4). We found that there are two principal teleost $\mathrm{pMCH}$ clades (pMCH- $\alpha$ and $\mathrm{pMCH}-\beta$ ) in the phylogenetic tree. of-pMCH1 is included in pMCH- $\alpha$ clade, a single large clade, which contains the majority of the teleost $\mathrm{pMCH}$ transcripts reported to date. In the POMC- $\alpha$ clade, there are duplicate genes from several flatfishes, such as, chinook salmon (cks-pMCH1, cks$\mathrm{pMCH} 2)$, rainbow trout (rt-pMCH1, rt-pMCH2), and chum salmon (cms-pMCH1, cms-pMCH2). This duplication have occurred later than the event which gave rise to the two principal teleost pMCH clades. of- $\mathrm{pMCH} 2$ is included in $\mathrm{pMCH}-\beta$ clade with the pMCH2 of winther flounder ( $w f-\mathrm{pMCH} 2)$, zebrafish ( $z b f$-pMCH2), and starry flounder ( $s f$-pMCH2).

\section{pMCH mRNA expression according to tissue and environmental factors}

Expression of the of-pMCH gene was detected by RT-PCR. An obvious single band of the expected size was obtained from the brain and pituitary, but a blurred single band was 

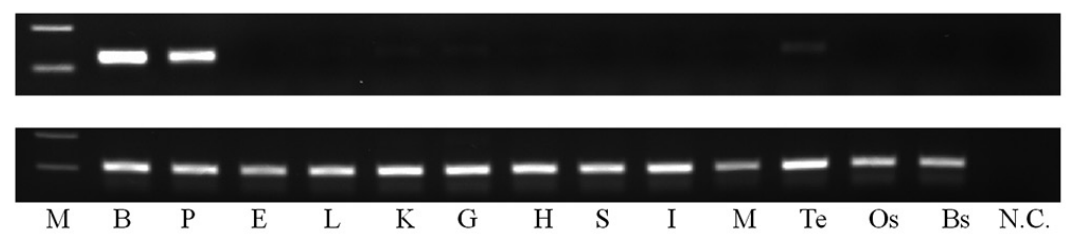

Fig. 5. Tissue distribution of of-pMCH in olive flounder Paralichthys olivaceus by RT-PCR. N.C. represents the negative control. Arrow indicates the expected size of pMCH (390 bp) (B: brain, P: pituitary, E: eye, L: liver, K: kidney, G: gill, H: heart, S: stomach, I: intestine, M: muscle, Te: testis, Os: ocular skin, Bs: blind skin, N.C.: negative control).

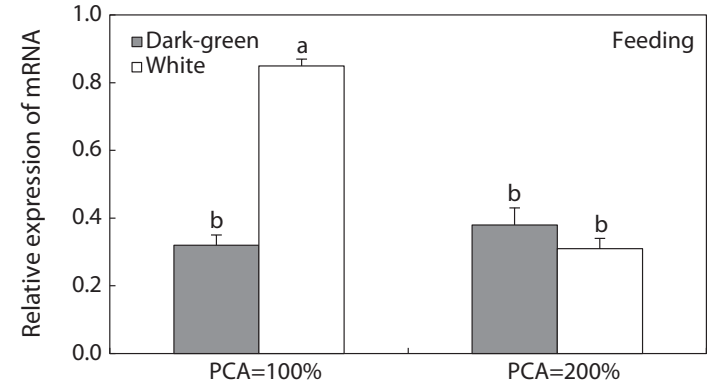

Fig. 6. Relative expressions of of-pMCH mRNA of olive flounders Paralichthys olivaceus cultured with a dark-green or white background at a density of $30 \mathrm{fish} / \mathrm{m}^{2}(\mathrm{PCA}=100 \%)$ or $60 \mathrm{fish} / \mathrm{m}^{2}(\mathrm{PCA}=200 \%)$. Each value represents the mean $\pm \operatorname{SEM}(n=5)$.

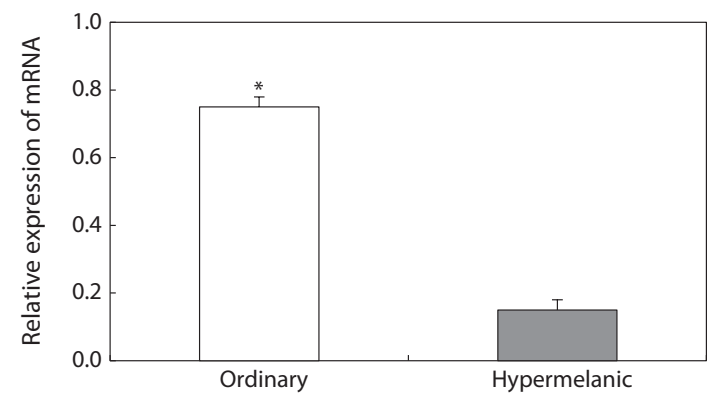

Fig. 7. Relative expressions of of-pMCH mRNA in ordinary and hypermelanic olive flounders Paralichthys olivaceus. Each value represents the mean $\pm \operatorname{SEM}(n=5)$.

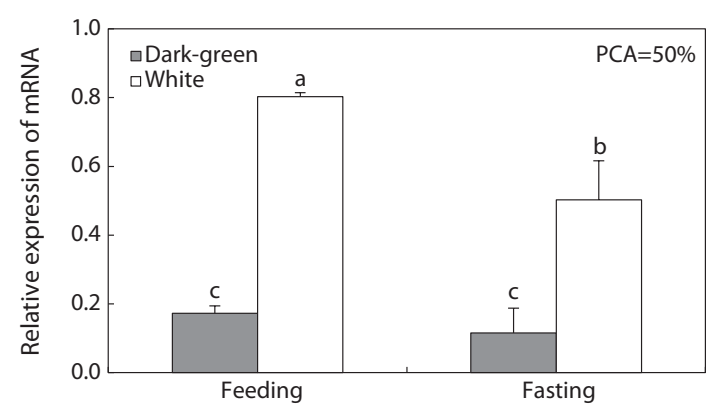

Fig. 8. Relative expressions of of-pMCH mRNA of olive flounders that had been feeding or fasting with a dark-green or white background at a density of $10 \mathrm{fish} / \mathrm{m}^{2}$ (PCA $=50 \%$ ). Each value represents the mean \pm SEM $(n=5)$. detected in the testis, gill, and kidney. No amplification of the pMCH gene transcript was detected in other tissues (Fig. 5). To examine the influence of environmental factors in $\mathrm{pMCH}$ mRNA activity in flatfish, we measured the relative activities of of-pMCH mRNA according to background color, density, and food intake. The level of gene expression was significantly higher in the white background group than the dark-green background group at $100 \%$ PCA $(P<0.05)$, but was not different between the two background colors at 200\% PCA (Fig. $6)$. The $\mathrm{pMCH}$ gene expression level was significantly lower in hypermelanic fish than in ordinary fish $(P<0.05$; Fig. 7). With respect to feeding, feeding fish reared at 50\% PCA showed significantly higher $o f-\mathrm{pMCH}$ gene expression than fasted fish with the white background $(P<0.05)$, but there was no significant difference between the two groups with the dark-green background ( $P>0.05$; Fig. 8$)$.

\section{Discussion}

The results of the present study indicated that $o f-\mathrm{pMCH}$ cDNA has a 405-bp ORF encoding a product of 135 amino acids, which consists of a signal peptide, N-pro MCH, NAL, and $\mathrm{MCH}$. In terms of amino acid sequence, the signal peptide, $\mathrm{N}$-pro $\mathrm{MCH}$, and NAL have undergone significant evolutionary changes, while $\mathrm{MCH}$ has been relatively well preserved. When the amino acid sequence of of-pMCH was compared with those deduced from the cDNAs of other teleost species, in terms of structure, of-pMCH has a high degree of similarity to the Pleuronectiformes and Perciformes pMCHs, but a low level of similarity to mammalian pMCHs. Similar to other fishes, including the barfin flounder (Takahashi et al., 2004), trout (Baker et al., 1995), salmon (Kawauchi et al., 1983; Nahon et al., 1991), tilapia (Groneveld et al., 1995), tuna (Kawauchi, 1989), and eel (Kawauchi, 2006), MCH is located at the $\mathrm{C}$-terminus of $\mathrm{pMCH}$ and consists of 17 amino acids (DNMRCMVGRVYRPCWEV; GenBank accession no. ABY73341). In comparison with other fishes, of-MCH is identical or similar to fish-type $\mathrm{MCH}(\mathrm{MCH} 1)$ in length and sequence. That is, it is structurally $100 \%$ identical to those of barfin flounder and starry flounder, and is $94.1 \%$ identical to those of the winter flounder and the spindle-shaped teleosts (dimerus, tilapia, salmon, puffer, etc.), showing outer N- 
terminal $(\mathrm{N})$ or one middle $(\mathrm{V})$ amino acid difference from those of other fishes. In addition, of-MCH has two fewer amino acids in the N-terminal than those of mammals, which are composed of 19 amino acids, and is $76.5 \%$ identical to mammalian homologs. With regard to length and sequence, of-MCH is significantly different from olive flounder $\mathrm{MCH}$ paralog (MCH-like peptide or MCH2; GenBank AF236090). The MCH paralog, consists of 25 amino acids (DTDFNMLRCMIGRVYRPCWESSNIP), and is structurally more similar to the Pleuronectiformes MCH2 and mammalian MCHs.

In phylogenetic trees (1,000 bootstrap replicates) of fish pMCHs, although a single pMCH was reported in many fish, duplicated pMCHs have also been described in several fish, such as salmon, zebrafish, and flounder species. Also, the phylogenetic analysis in the present study reveals that there are two main clades (pMCH- $\alpha$ and pMCH- $\beta$ ) and that, in some teleost species, the loss of $\mathrm{pMCH}-\beta$ gene was occurred under different selective pressures during their evolution. Here, we confirmed that olive flounder has two pMCHs, indicating that flounder species may have two types of $\mathrm{pMCH}$. Based on aa comparisons and phylogenetic trees, of-pMCH is considered invariant copies because they have typical $\mathrm{MCH}$ (DN[T]MRCMVGRVYRPCWEV) . This gene is included in pMCH- $\alpha$ clade with the majority of the teleost pMCH genes. Also, in pMCH $\alpha$-clade, the of-pMCH was not included in the salmoniformes clade, but was instead in a separate clade containing Pleuronectiformes and Perciformes. Interestingly, the of-pMCH was included in the same clade as dimerus and tilapia, which are neither marine fish nor pleuronectiforms. This supported the suggestion that Pleuronectiformes evolved from Zeiformes or Perciformes, related to Percoidei (Friedman, 2008). Our phylogenetic data also indicated that the of-pMCH is far from the clade of of-pMCH2, close to the clade of human pMCH. The of-pMCH2 is included in POMC- $\beta$ clade with the pMCH2 of winther flounder ( $w f$-pMCH2, GenBank AEE36640), zebrafish (zbf-pMCH2, GenBank ACO35934), and starry flounder ( $s f$-pMCH2, GenBank KF621305). This gene retains structural characteristics of variant copies because mutations are present in its MCH (DFN[ $\underline{\mathrm{ID}}] \mathrm{M}[\underline{\mathrm{L}}] \mathrm{LRCMI}[\underline{\mathrm{V}}]$ GRVYRPCE). This suggested that fish pMCH2 and human pMCH may have evolved from fish pMCH of $\alpha$-clade. Fish pMCH2 and human MCH may have become specialized and diverged from a common ancestor (fish MCH1) during evolution. Thus, other bony fishes may also possess a different paralog $\mathrm{MCH}$ precursor (or mature $\mathrm{MCH}$ ) similar to that of mammals. Recently, it was discovered that the genomes of zebrafish, winter flounder, and other teleosts encode two distinct $\mathrm{MCH}$ peptides: one (MCH1) similar or identical to the salmonid $\mathrm{MCH}$, and one $(\mathrm{MCH} 2)$ that bears a striking resemblance to mammalian MCH. Chinook trout (Minth et al., 1989), chum salmon (Takayama et al., 1989), and rainbow trout (Baker et al., 1995) possess two precursors with the same type of $\mathrm{MCH}$ sequence, while zebrafish (Berman et al., 2009), winter flounder (Tuziak and Volkoff, 2012), and starry flounder (Kang and Kim, 2013) possess two precursors with another type of $\mathrm{MCH}$ sequence, indicating that fishes also have two types of $\mathrm{pMCH}$. These results suggest that olive flounder has two types of $\mathrm{MCH}$ with different functions, as Tuziak and Volkoff (2012) reported that MCH1 participates in skin pigmentation and $\mathrm{MCH} 2$ activates appetite. Indeed, it has been reported that the fish $\mathrm{MCH}(\mathrm{MCH} 1)$ regulates physiological color change (Kishida et al., 1989; Suzuki et al., 1995; Kawauchi, 2006), and that the mammalian $\mathrm{MCH}(\mathrm{MCH} 2)$ is involved in food intake behavior and energy homeostasis in mammals (Pritchard et al., 2002; Shi, 2004; Pissios et al., 2006) and fishes (Mizusawa et al., 2009; Kang and Kim, 2013).

In this study, we examined the expression of pMCH mRNA in cranial and extracranial organs. Obvious expression of pMCH mRNA was detected in the brain and pituitary. In contrast, a week expression was observed in testis, kidney, and gill, and no expression was observed in the other tissues examined. These observations are consistent with previous reports in other teleost fishes (Naito et al., 1985; Minth et al., 1989; Amano et al., 2003; Pandolfi et al., 2003). In addition, although it is not clear whether $\mathrm{MCH}$ expression in extracranial organs is of physiological significance, the MCH mRNA expression in the testis, kidney, and gill suggests that MCHs play a peripheral role in spermatogenesis and osmoregulation. Therefore, further studies are needed to determine the peripheral physiological roles of $\mathrm{MCH}$ transcripts in extracranial organs.

In the wild, fish often use camouflage to hide from predators. One camouflage tactic is to change the body color to match that of the current background. $\mathrm{MCH}$, a functional antagonist of $\alpha$-MSH, plays a key role in this type of color change (Baker, 1993; Suzuki et al., 1995). Previous studies demonstrated that many fishes physiologically change their body color to match the background color with changes in $\mathrm{MCH}$ gene expression (Ramachandran et al., 1996; Nery and Castrucci, 1997; Nilsson Sköld et al., 2013). In pleuronectiforms, Amiya et al. (2005), Amano and Takahashi (2009), and Yamanome et al. (2005) demonstrated that a bright background color increases $\mathrm{MCH}$ gene expression, and then sequentially brightens body color, finally suppressing the blind-side malpigmentation of cultivated flounders. However, in the present study, we found that bright background did not whiten ocular skin, and MCHs do not play a role in the whitening of ocular skin in the olive flounder. The function of $\mathrm{MCH}$ in the whitening of ocular skin and bright background was found only at a fish density of $100 \%$ PCA, and not at the higher density of $200 \%$ PCA. These unexpected results indicated that overcrowding may suppress $\mathrm{MCH}$ action in the whitening of skin color, and that $\mathrm{MCH}$ is hindered by high density (200\% PCA or higher).

In the present study, we investigated whether $\mathrm{MCH}$ was related to blind-side hypermelanosis by comparing the expression of of-pMCH mRNA between ordinary and malpigmented flounders. The of-pMCH expression level was significantly lower in hypermelanic flounders, indicating that low 
MCH mRNA expression in hypermelanic fish may be related to blind-side hypermelanosis. A dark background color was shown to depress $\mathrm{MCH}$ gene expression (Kobayashi et al., 2008), and then sequentially increase the blind-side malpigmentation of cultivated flounders (Yamanome et al., 2007b; Yamanome et al., 2007a). Therefore, hypermelanosis on the blind side could be prevented by increasing endogenous $\mathrm{MCH}$. Indeed, although these tests were performed at a low density, Takahashi et al. (2004), Yamanome et al. (2005), and Amiya et al. $(2005,2008)$ reported that hypermelanosis on the blind side of flatfish could be inhibited by increased endogenous $\mathrm{MCH}$ activity in the white background tanks. However, it remains unknown whether $\mathrm{MCH}$ is related to the morphological color change on the blind side in other pleuronectiforms. It is not yet clear why the morphological color change occurs with decreasing $\mathrm{MCH}$ activity when flatfish are unable to burrow in a normal manner at high density (PCA $>200 \%$ ). To determine why blind-side malpigmentation occurs mostly under artificial rearing conditions without a burrowing substratum at high density, it will be necessary to investigate the relationships between physiological color hormones and abnormal pigmentation from an epigenetic standpoint.

Several studies (Groneveld et al., 1995; Suzuki et al., 1995; Amiya et al., 2005; Yamanome et al., 2005; Takahashi et al., 2007) have indicated that a bright background color increases appetite and growth in fishes through markedly increasing hypothalamic $\mathrm{MCH}$ neurons and triggering $\mathrm{MCH}$ production in the brain, suggesting that an $\mathrm{MCH}$-related signaling system activated by white background stimulates food intake, which in turn accelerates growth in fishes. Previous studies (Takahashi et al., 2004; Yamanome et al., 2005; Matsuda et al., 2006; Matsuda et al., 2009) have reported that this hormone is also involved in improving appetite in teleosts. Recently, this was also supported by Berman et al. (2009) who found that fasted fishes had greater numbers of detectable $\mathrm{MCH}-$ immunoreactive cell bodies in the brain than fed fish, and by Takahashi et al. (2004), Tuziak and Volkoff (2012), and Kang and Kim (2013) who found that MCH gene expression in the brain of starved fish was two-fold greater than that in fed fish. The relevance of $\mathrm{MCH}$ to appetite in fish may follow a similar pattern as in mammals; i.e., mammalian-like $\mathrm{MCH}$ in combination with neuropeptide circuits (neuropeptide Y, hypocretin, and agouti-related protein) regulates food intake (Lin et al., 2000; Kawauchi, 2006; Matsuda and Maruyama, 2007). However, our data did not indicate that $\mathrm{MCH}$ is related to food intake. In the present feeding test, when flounders were reared at $50 \%$ PCA, pMCH gene activity was significantly higher with a bright background color than a dark background color, regardless of feeding or fasting. However, the effects of food intake on $\mathrm{pMCH}$ gene activity were dependent on background color. Although pMCH gene activity was significantly twofold higher in the feeding group than the fasting group with a white background, the gene activity with a dark-green background was not significantly different between the two groups.
Therefore, our results indicate that the $\mathrm{MCH}$ system is under the control of background color, but is not under the control of food intake. However, in previous studies using other flounder species (Takahashi et al., 2004; Tuziak and Volkoff, 2012; Kang and Kim, 2013), brain MCH mRNA levels were increased markedly under fasting conditions. In these studies, ordinary barfin flounder (Takahashi et al., 2004), winter flounder (Tuziak and Volkoff, 2012), and starry flounder (Kang and Kim, 2013) were reared in flat-bottomed black tanks, sandybottomed white tanks, and gravel-bottomed dark-green tanks, respectively. However, in the present study, we did not find any increase in $\mathrm{MCH}$ gene expression under fasting conditions regardless of background color or tank bottom type. Rather, in the white tank, MCH was significantly increased in the feeding group. These discrepancies in the results were likely caused by interference of background color; i.e., our contradictory results may have been due to the different background color and type of tank bottom employed to evaluate the role of MCH in food intake. Recently, Berman et al. (2009) and Tuziak and Volkoff (2012) reported the existence of two functionally distinct $\mathrm{MCH}$ peptides, and disagreed over the relationship of the fish-type $\mathrm{MCH}$ gene with food intake. Although Tuziak and Volkoff (2012) suggested that the fish-type $\mathrm{MCH}$ gene plays a role in regulation of appetite in flounder, Berman et al. (2009) suggested that the fish-type $\mathrm{MCH}$ gene is not principally involved in pigmentation and that the mammalian-type $\mathrm{MCH}$ gene is responsive to changes in appetite. Therefore, the relevance of fish-type $\mathrm{MCH}$ to the availability of food in fish must be examined carefully, and further experiments are necessary to determine whether the fish-type $\mathrm{MCH}$ is functionally related to feeding.

In conclusion, the primary structure of of-pMCH is similar to those of other fish species, but differs from mammalian $\mathrm{pMCH}$. In addition, the of-pMCH mRNA levels were higher in the brain and pituitary than in other organs, indicating that the cranial organs are the main areas of $\mathrm{MCH}$ production. In addition, of-pMCH gene expression level was increased with a white background color at low density ( $<100 \%$ PCA), but was suppressed by a dark background color and at high density ( $>200 \%$ PCA), indicating that $\mathrm{MCH}$ is primarily related to white color camouflage in flounders against a white color background, and that density is an important factor in $\mathrm{MCH}$ gene expression. Moreover, pMCH mRNA expression is weak in hypermelanic flounders malpigmented on their blind-side skin but is strong in ordinary flounders, suggesting that 1 week of $\mathrm{MCH}$ expression could induce abnormal morphological color changes (pigment cell differentiation). However, we did not find a direct relationship between $\mathrm{MCH}$ and appetite.

\section{References}

Abbott CR, Kennedy AR, Wren AM, Rossi M, Murphy KG, Seal LJ, Todd JF, Ghatei MA, Small CJ and Bloom SR. 2003. Identifica- 
tion of hypothalamic nuclei involved in the orexigenic effect of melanin-concentrating hormone. Endocrinology 144, 3943-3949.

Amano M and Takahashi A. 2009. Melanin-concentrating hormone: A neuropeptide hormone affecting the relationship between photic environment and fish with special reference to background color and food intake regulation. Peptides 30, 1979-1984.

Amano M, Takahashi A, Oka Y, Yamanome T, Kawauchi H and Yamamori K. 2003. Immunocytochemical localization and ontogenic development of melanin-concentrating hormone in the brain of a pleuronectiform fish, the barfin flounder. Cell Tiss Res 311, 71-77.

Amiya N, Amano M, Takahashi A, Yamanome T, Kawauchi H and Yamamori K. 2005. Effects of tank color on melanin-concentrating hormone levels in the brain, pituitary gland, and plasma of the barfin flounder as revealed by a newly developed time-resolved fluoroimmunoassay. Gen Comp Endocrinol 143, 251-256.

Baker B, Levy A, Hall L and Lightman S. 1995. Cloning and expression of melanin-concentrating hormone genes in the rainbow trout brain. Neuroendocrinology 61, 67-76.

Baker BI. 1993. The role of melanin-concentrating hormone in color change. Annals New York Acad Sci 680, 279-289.

Berman JR, Skariah G, Maro GS, Mignot E and Mourrain P. 2009. Characterization of two melanin-concentrating hormone genes in zebrafish reveals evolutionary and physiological links with the mammalian MCH system. J Comp Neurol 517, 695-710.

Della-Zuana O, Presse F, Ortola C, Duhault J, Nahon JL and Levens N. 2002. Acute and chronic administration of melanin-concentrating hormone enhances food intake and body weight in Wistar and Sprague-Dawley rats. Internat J Obesity 26, 1289-1295.

Doolan BJ, Allan GL, Booth MA and Jones PL. 2008. Effects of cage netting colour and density on the skin pigmentation and stress response of Australian snapper, Pagrus auratus (Bloch \& Schneider, 1801). Aquacult Res 39, 1360-1368.

Gomori A, Ishihara A, Ito M, Mashiko S, Matsushita H, Yumoto M, Ito M, Tanaka T, Tokita S, Moriya M, Iwaasa H and Kanatani A. 2003. Chronic intracerebroventricular infusion of $\mathrm{MCH}$ causes obesity in mice. Am J Physiol-Endocrinol Metabol 284, E583-E588.

Groneveld D, Eckhardt ERM, Coenen AJM, Martens GJM, Balm PHM and Wendelaar Bonga SE. 1995. Expression of tilapia prepro-melanin-concentrating hormone mRNA in hypothalamic and neurohypophysial cells. J Molec Endocrinol 14, 199-207.

Höglund E, Balm PHM and Winberg S. 2002. Behavioural and neuroendocrine effects of environmental background colour and social interaction in Arctic charr (Salvelinus alpinus). J Exper Biol 205, 2535-2543.

Han D, Xie S, Lei W, Zhu X and Yang Y. 2005. Effect of light intensity on growth, survival and skin color of juvenile Chinese longsnout catfish (Leiocassis longirostris Günther). Aquaculture 248, 299306.

Iwata N and Kikuchi K. 1998. Effects of sandy substrate and light on hypermelanosis of the blind side in cultured Japanese flounder Paralichthys olivaceus. Environ Biol Fish 52, 291-297.

Jeong DS and Jeon CY. 2008. Genetic variability and population structure of olive flounder Paralichthys olivaceus from stocked areas using microsatellite DNA markers. Kor J Ichthyol 20, 156-162.
Kalinowski CT, Robaina LE, Fernández-Palacios H, Schuchardt D and Izquierdo MS. 2005. Effect of different carotenoid sources and their dietary levels on red porgy (Pagrus pagrus) growth and skin colour. Aquaculture 244, 223-231.

Kang DY and Kim HC. 2012. Relevance of environmental factors and physiological pigment hormones to blind-side hypermelanosis in the cultured flounder, Paralichthys olivaceus. Aquaculture 356357, 14-21.

Kang DY and Kim HC. 2013. Functional characterization of two melanin-concentrating hormone genes in the color camouflage, hypermelanosis, and appetite of starry flounder. Gen Comp Endocrinol $189,74-83$.

Kang DY, Kim HC and Chang YJ. 2011. Effects of stocking density on the blind-side hypermelanosis of cultured olive flounder Paralichthys olivaceus. Fish Aquat Sci 14, 123-129.

Kawauchi H. 1989. Structure and biosynthesis of melanin-concentrating hormone. Life Sci 45, 1133-1140.

Kawauchi H. 2006. Functions of melanin-concentrating hormone in fish. J Exper Zool-part A: Comp Exper Biol 305, 751-760.

Kawauchi H and Baker BI. 2004. Melanin-concentrating hormone signaling systems in fish. Peptides 25, 1577-1584.

Kawauchi H, Kawazoe I and Tsubokawa M. 1983. Characterization of melanin- concentrating hormone in chum salmon pituitaries. Nature 305, 321-323.

Kishida M, Baker BI and Eberle AN. 1989. The measurement of melanin-concentrating hormone in trout blood. Gen Comp Endocrinol 74, 221-229.

Kobayashi Y, Chiba H, Amiya N, Yamanome T, Mizusawa K, Amano $\mathrm{M}$ and Takahashi A. 2008. Transcription elements and functional expression of proopiomelanocortin genes in the pituitary gland of the barfin flounder. Gen Comp Endocrinol 158, 259-267.

Lin X, Volkoff H, Narnaware Y, Bernier NJ, Peyon P and Peter RE. 2000. Brain regulation of feeding behavior and food intake in fish. Comp Biochem Physiol- part A. Molec Integr Physiol 126, 415434.

Livak KJ and Schmittgen TD. 2001. Analysis of relative gene expression data using real-time quantitative PCR and the $2^{-\triangle \Delta C T}$ method. Methods 25, 402-408.

Ludwig DS, Mountjoy KG, Tatro JB, Gillette JA, Frederich RC, Flier JS and Maratos-Flier E. 1998. Melanin-concentrating hormone: A functional melanocortin antagonist in the hypothalamus. Am J Physiol- Endocrinol Metabol 274, E627-E633.

Matsuda K and Maruyama K. 2007. Regulation of feeding behavior by pituitary adenylate cyclase-activating polypeptide (PACAP) and vasoactive intestinal polypeptide (VIP) in vertebrates. Peptides 28, 1761-1766.

Matsuda K, Kojima K, Shimakura SI and Takahashi A. 2009. Regulation of food intake by melanin-concentrating hormone in goldfish. Peptides 30, 2060-2065.

Matsuda K, Shimakura SI, Maruyama K, Miura T, Uchiyama M, Kawauchi H, Shioda S and Takahashi A. 2006. Central administration of melanin-concentrating hormone ( $\mathrm{MCH})$ suppresses food intake, but not locomotor activity, in the goldfish, Carassius auratus. Neurosci Lett 399, 259-263. 
Matsuda K, Shimakura SI, Miura T, Maruyama K, Uchiyama M, Kawauchi H, Shioda S and Takahashi A. 2007. Feeding-induced changes of melanin-concentrating hormone ( $\mathrm{MCH}$ )-like immunoreactivity in goldfish brain. Cell Tiss Res 328, 375-382.

Minth CD, Qiu H, Akil H, Watson SJ and Dixon JE. 1989. Two precursors of melanin-concentrating hormone: DNA sequence analysis and in situ and immunochemical localization. Proc Nat' Acad Sci US Am 86, 4292-4296.

Mizusawa K, Saito Y, Wang Z, Kobayashi Y, Matsuda K and Takahashi A. 2009. Molecular cloning and expression of two melanin-concentrating hormone receptors in goldfish. Peptides 30, 1990-1996.

Nahon JL, Presse F, Schoepfer R and Vale W. 1991. Identification of a single melanin-concentrating hormone messenger ribonucleic acid in coho salmon: Structural relatedness with 7SL ribonucleic acid. J Neuroendocrinol 3, 173-183.

Naito N, Nakai Y, Kawauchi H and Hayashi Y. 1985. Immunocytochemical identification of melanin-concentrating hormone in the brain and pituitary gland of the teleost fishes Oncorhynchus keta and Salmo gairdneri. Cell Tiss Res 242, 41-48.

Nery LEM and Castrucci AMDL. 1997. Pigment cell signalling for physiological color change. Comp Biochem Physiol-part A. Physiol 118, 1135-1144.

Nilsson Sköld H, Aspengren S and Wallin M. 2013. Rapid color change in fish and amphibians-function, regulation, and emerging applications. Pigment Cell Melano Res 26, 29-38.

Oshima N. 2001. Direct reception of light by chromatophores of lower vertebrates. Pigment Cell Res 14, 312-319.

Ottesen OH and Strand HK. 1996. Growth, development, and skin abnormalities of halibut (Hippoglossus hippoglossus L.) juveniles kept on different bottom substrates. Aquaculture 146, 17-25.

Pérez Sirkin DI, Cánepa MM, Fossati M, Fernandino JI, Delgadin T, Canosa LF, Somoza GM and Vissio PG. 2012. Melanin concentrating hormone $(\mathrm{MCH})$ is involved in the regulation of growth hormone in Cichlasoma dimerus (Cichlidae, Teleostei). Gen Comp Endocrinol 176, 102-111.

Pandolfi M, Cánepa MM, Ravaglia MA, Maggese MC, Paz DA and Vissio PG. 2003. Melanin-concentrating hormone system in the brain and skin of the cichlid fish Cichlasoma dimerus: Anatomical localization ontogeny and distribution in comparison to $\alpha$-melanocytestimulating hormone-expressing cells. Cell Tiss Res 311, 61-69.

Pissios P, Bradley RL and Maratos-Flier E. 2006. Expanding the scales: The multiple roles of $\mathrm{MCH}$ in regulating energy balance and other biological functions. Endoc Rev 27, 606-620.

Presse F, Sorokovsky I, Max JP, Nicolaidis S and Nahon JL. 1996. Melanin-concentrating hormone is a potent anorectic peptide regulated by food-deprivation and glucopenia in the rat. Neuroscience 71 , 735-745.

Pritchard LE, Turnbull AV and White A. 2002. Pro-opiomelanocortin processing in the hypothalamus: Impact on melanocortin signalling and obesity. J Endocrinol 172, 411-421.

Qu D, Ludwig DS, Gammeltoft S, Piper M, Pelleymounter MA, Cullen MJ, Mathes WF, Przypek J, Kanarek R and Maratos-Flier E. 1996. A role for melanin-concentrating hormone in the central regulation of feeding behaviour. Nature 380, 243-247.
Ramachandran VS, Tyler CW, Gregory RL, Rogers-Ramachandran D, Duensing S, Pillsbury C and Ramachandran C. 1996. Rapid adaptive camouflage in tropical flounders. Nature 379, 815-818.

Rossi M, Choi SJ, O'Shea D, Miyoshi T, Ghatei MA and Bloom SR. 1997. Melanin-concentrating hormone acutely stimulates feeding, but chronic administration has no effect on body weight. Endocrinology 138, 351-355.

Seikai T. 1992. Process of pigment cell differentiation in skin on the left and right side of the Japanese flounder, Paralichthys olivaceus, during metamorphosis. Jap J Ichthyol 29, 85-92.

Seikai T, Matsumoto J, Shimozaki M, Oikawa A and Akiyama T. 1987. An association of melanophores appearing at metamorphosis as vehicles of asymmetric skin color formation with pigment anomalies developed under hatchery conditions in the Japanese flounder, Paralichthys olivaceus. Pigment cell research 1, 143-151.

Shi Y. 2004. Beyond skin color: Emerging roles of melanin-concentrating hormone in energy homeostasis and other physiological functions. Peptides 25, 1605-1611.

Stricker-Krongrad A, Dimitrov T and Beck B. 2001. Central and peripheral dysregulation of melanin-concentrating hormone in obese Zucker rats. Mol Brain Res 92, 43-48.

Sugimoto M. 2002. Morphological color changes in fish: Regulation of pigment cell density and morphology. Microscopy Res Tech 58, 496-503.

Suzuki M, Narnaware YK, Baker BI and Levy A. 1995. Influence of environmental colour and diurnal phase on $\mathrm{MCH}$ gene expression in the trout. J Neuroendocrinol 7, 319-328.

Tagawa M, Kaji T, Kinoshita M and Tanaka M. 2004. Effect of stocking density and addition of proteins on larval survival in Japanese flounder, Paralichthys olivaceus. Aquaculture 230, 517-525.

Takahashi A, Kosugi T, Kobayashi Y, Yamanome T, Schiöth HB and Kawauchi H. 2007. The melanin-concentrating hormone receptor 2 (MCH-R2) mediates the effect of $\mathrm{MCH}$ to control body color for background adaptation in the barfin flounder. Gen Comp Endocrinol 151, 210-219.

Takahashi A, Tsuchiya K, Yamanome T, Amano M, Yasuda A, Yamamori K and Kawauchi H. 2004. Possible involvement of melaninconcentrating hormone in food intake in a teleost fish, barfin flounder. Peptides 25, 1613-1622.

Takahashi Y. 1994. Influence of stocking density and food at late phase of larval period on hypermelanosis on the blind body side in juvenile Japanese flounder. Nippon Suisan Gakkaishi 60, 593-598.

Takayama Y, Wada C, Kawauchi H and Ono M. 1989. Structures of two genes coding for melanin-concentrating hormone of chum salmon. Gene 80, 65-73.

Tamura K, Dudley J, Nei M and Kumar S. 2007. MEGA4: Molecular Evolutionary Genetics Analysis (MEGA) software version 4.0. Molecular Biology and Evolution 24, 1596-1599.

Tuziak SM and Volkoff H. 2012. A preliminary investigation of the role of melanin-concentrating hormone $(\mathrm{MCH})$ and its receptors in appetite regulation of winter flounder (Pseudopleuronectes americanus). Molec Cell Endocrinol 348, 281-296.

Yamanome T, Amano M and Takahashi A. 2005. White background reduces the occurrence of staining, activates melanin-concentrating 
Kang et al. (2014) Relevance of pMCH to skin color change

hormone and promotes somatic growth in barfin flounder. Aquaculture 244, 323-329.

Yamanome T, Chiba H and Takahashi A. 2007a. Melanocyte-stimulating hormone facilitates hypermelanosis on the non-eyed side of the barfin flounder, a pleuronectiform fish. Aquaculture 270, 505-511.
Yamanome T, Amano M, Amiya N and Takahashi A. 2007b. Hypermelanosis on the blind side of Japanese flounder Paralichthys olivaceus is diminished by rearing in a white tank: Short paper. Fish Sci 73, 466-468. 